\title{
Sulfonylurea 剤治療中糖尿病患者の血中脂質に
}

\section{及ぼす Clinofibrate の影響*}

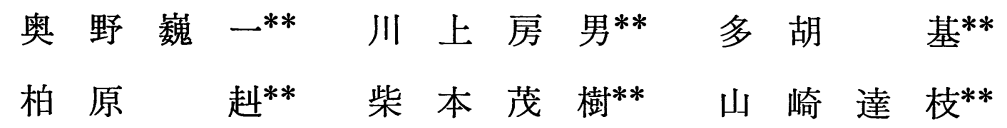

\section{I.はじめに}

血中 HDL-Cholesterol (HDL-C) を上昇または 抑制する因子は多く知られるが，Sulfonylurea (SU) 剂は少なくとも HDL-C 研究初期の段階で はその血中濃度を低下せしめるとされた。しかし その後の報告, 特に本邦に抒ける学会報告 ${ }^{1 \sim 3)}$ は 必ずしもこれを支持しない。一方 Clinofibrate (CF) は VLDL および LDL 分画の Cholesterol (CH), Triglyceride (TG) を低下，HDL-C を上昇 せしめ近年広く抗脂血症剤として使われる。そこ で SU 剂治療中の血中脂質，ことに HDL-C が食 事療法群に比し低下しているか否かと，第 2 に SU 治療中糖尿病例で高脂血症を呈する患者に CF を長期投与し，HDL-C を始め他の血中脂 質 に与える影響を検討した.

\section{II. 対象と方法}

当院糖尿病外来に通院中の糖尿病患者で血糖調 節が恒常状態にある SU 治療中の患者のうちなお 高脂血症を呈する 17 例に，現在の治療はそのま ま変更しないで CF を $600 \mathrm{mg} /$ 日，約 1 年間投与 した. $\mathrm{CH}$ はシノテスト, HDL-C はへパリン・カ ルシウム改良法, TG はパラクロール・フェノー ル発色法にて測定し, Atherogenic Index (AI) は HDL-C $/ \mathrm{CH} \times 100$ で計算した．脂質測定は原則と して CF 投与前 2 回の平均值 と, 投与後は 2 週, 4 週， 2 か月と以後は少なくとも 2 か月に 1 回の 割合で測定，投与期間は約 1 年であるが，最長投

* 1983年 7月, 第15回日本動脈硬化学会において発表 ** 市立伊丹病院内科
与例は 17 か月に及んでいる. 高脂血症の基準 と して当院では従来より $\mathrm{CH} 240 \mathrm{mg} / \mathrm{d} l$ 以上, TG $120 \mathrm{mg} / \mathrm{d} l$ 以上のいずれか一方または双方を満た すものとしている.

次に同じく血糖調節の安定した SU 投与中患者 33 例の数か月間における少なくとも 4 回以上の 血中脂質值の平均を CF 投与群の対照とした. 一 方 SU 群の対照として, 食事療法群 15 例と, 食 事療法をつづけながらなお高脂血症を呈する 7 例 にCF を投与し同様に脂質を測定した. 以上の研 究対象 4 群の年齢, 糖尿病罹病期間, 血糖調節を Table 1 に示すが，年齢と罹病期間はほぼマッチ している.

\section{III. 成 績}

Table 2 は最近 1 年間の当院受診糖尿病のうち 未治療時に血中脂質を測定した 56 例の各脂質值 を男女別に示したものである．表にはあらわれて いないが，当院での最近 1 か月における正常者の HDL-C の值は, 男 $42.7 \pm 11.0 \mathrm{mg} / \mathrm{d} l(\mathrm{~N}=397)$, 女 $49.5 \pm 11.4 \mathrm{mg} / \mathrm{d} l(\mathrm{~N}=372)$, 計 $46.1 \pm 11.6 \mathrm{mg} / \mathrm{d} l$ $(\mathrm{N}=769, \mathrm{M} \pm \mathrm{SD})$ で，したがって未治療糖尿病 の HDL-C は正常者より低下しているとは言えな い. Table 3 は以上の 56 例の脂質を未治療時空 腹時血糖 (FBS) 別に分けたもので FBS による差 は明らかでないが，HDL-C は FBS の高くなる 程上昇傾向をみせている.

\section{1. 総括成績}

Table 4 は成績の総括で, $\mathrm{CF}$ 投与前後の脂質 值と，投与前に対する投与後の \% 值をカッコ内 に示す．方法で述べたように食事または SU 治療 
動脈硬化 Vol. 12 No. 2 June 1984

Table 1 Diabetic control, ages and duration of diabetes in patients given Clinofibrate (CF)

\begin{tabular}{lrrccccc}
\hline & & \multicolumn{3}{c}{ Control } & & Duration & Age \\
\cline { 3 - 5 } & & good & fair & poor & & (years) & \\
\hline Diet & 15 & 15 & 0 & 0 & $6.4 \pm 4.1$ & $65.2 \pm 6.5$ \\
Diet + CF & 7 & 7 & 0 & 0 & $6.7 \pm 5.8$ & $59.0 \pm 9.0$ \\
Sulfonylurea & 33 & 19 & 11 & 3 & $9.5 \pm 4.1$ & $64.2 \pm 8.9$ \\
Sulfonylurea + CF & 17 & 8 & 4 & 4 & $6.9 \pm 4.4$ & $62.0 \pm 11.2$ \\
\hline
\end{tabular}

Table 2 Blood lipid of untreated diabetics

\begin{tabular}{lcccc}
\hline & & Male (26) & Female (30) & Total (56) \\
\hline Cholesterol & $\mathrm{mg} / \mathrm{d} l$ & $216.3 \pm 6.1$ & $231.9 \pm 8.8$ & $224.7 \pm 5.6$ \\
HDL-Chol. & $\mathrm{mg} / \mathrm{d} l$ & $48.8 \pm 2.3$ & $56.4 \pm 2.7$ & $52.9 \pm 1.9$ \\
A. I. & & $23.1 \pm 1.4$ & $24.6 \pm 1.2$ & $23.9 \pm 0.9$ \\
Triglyceride & $\mathrm{mg} / \mathrm{d} l$ & $170.8 \pm 23.7$ & $163.0 \pm 27.2$ & $166.7 \pm 18.1$ \\
\hline
\end{tabular}

$(\mathrm{M} \pm \mathrm{SE}) * \mathrm{HDL}-\mathrm{C} / \mathrm{Chol} \times 100$

Table 3 Blood lipid of untreated diabetics in relation to fasting blood glucose

\begin{tabular}{lccccc}
\hline FBS & $\mathrm{mg} / \mathrm{d} l$ & -199 & 200 & 300 & Total \\
\hline N. & & 24 & 25 & 7 & 56 \\
\hline Cholesterol & $\mathrm{mg} / \mathrm{d} l$ & $220.9 \pm 8.4$ & $234.1 \pm 8.1$ & $204.1 \pm 16.6$ & $224.7 \pm 5.6$ \\
HDL-Chol. & $\mathrm{mg} / \mathrm{d} l$ & $50.8 \pm 2.7$ & $53.8 \pm 2.6$ & $56.4 \pm 7.2$ & $52.9 \pm 1.9$ \\
A. I. & & $23.4 \pm 1.4$ & $23.2 \pm 1.0$ & $28.0 \pm 3.4$ & $23.9 \pm 0.9$ \\
Triglyceride & $\mathrm{mg} / \mathrm{d} l$ & $169.8 \pm 32.4$ & $163.6 \pm 25.6$ & $166.9 \pm 29.6$ & $166.7 \pm 18.1$ \\
\hline
\end{tabular}

$(\mathrm{M} \pm \mathrm{SE}) * \mathrm{HDL}-\mathrm{C} / \mathrm{Chol} \times 100$

Table 4 Changes of blood lipid in diabetics after $600 \mathrm{mg} /$ day administration of Clinofibrate

\begin{tabular}{|c|c|c|c|c|c|c|c|c|}
\hline \multirow{2}{*}{ Treatment } & \multirow{2}{*}{$\underset{n=15}{D}$} & \multicolumn{3}{|c|}{$\mathrm{D}+\mathrm{CF}, \mathrm{n}=7$} & \multirow{2}{*}{$\underset{n=33}{\mathrm{SU}}$} & \multicolumn{3}{|c|}{$\mathrm{SU}+\mathrm{CF}, \mathrm{n}=7$} \\
\hline & & before & after & $(\%)$ & & before & after & $(\%)$ \\
\hline Cholesterol & 202.6 & 266.7 & 223.1 & (83.8) & 216.0 & 250.5 & 222.3 & $(88.8)$ \\
\hline $\mathrm{mg} / \mathrm{d} l$ & \pm 7.8 & \pm 13.0 & \pm 7.7 & & \pm 6.1 & \pm 6.9 & \pm 10.6 & \\
\hline HDL-Chol. & 51.8 & 44.3 & 48.0 & (109) & 55.8 & 41.2 & 47.7 & (114) \\
\hline $\mathrm{mg} / \mathrm{d} l$ & \pm 3.6 & \pm 4.8 & \pm 1.6 & & \pm 1.9 & \pm 3.8 & \pm 2.9 & \\
\hline Atherogenic & 30.9 & 16.4 & 22.0 & (137) & 26.3 & 17.3 & 22.3 & (129) \\
\hline Index* & \pm 3.3 & \pm 2.0 & \pm 1.2 & & \pm 1.0 & \pm 1.6 & \pm 1.9 & \\
\hline Triglyceride & 85.0 & 202.6 & 151.1 & (74.4) & 105.8 & 263.2 & 199.0 & (75.6) \\
\hline $\mathrm{mg} / \mathrm{d} l$ & \pm 5.9 & \pm 30.9 & \pm 13.6 & & \pm 7.7 & \pm 28.0 & \pm 27.0 & \\
\hline
\end{tabular}

*HDL-C/Chol $\times 100$, D: Diet, SU: Sulfonylurea, CF: Clinofibrate

$(\mathrm{M} \pm \mathrm{SE})$

でなお高脂血症を呈する症例に CF を投与したの で投与前值は非投与群より当然のことながら異常 值を示している. CF 投与後 SU 群においては $\mathrm{CH}$ は前值の $88 \%$ に, TG は同じく $75 \%$ に低下 し, HDL-C は逆に $114 \%$ に増加した. すなわち CF は SU 投与中といえども HDL-C を上昇傾向 に向かわせ， $\mathrm{CH}, \mathrm{TG}$ は低下せしめる. また食事
療法群においても CF によりほぼ同程度の脂質改 善効果が得られた. SU 群の HDL-C $55.8 \pm 1.9$ $\mathrm{mg} / \mathrm{d} l$ は食事療法群の $51.8 \pm 3.6 \mathrm{mg} / \mathrm{d} l$ に比べむ しろ高い傾向にあり，CF 投与群の前值でも $\mathrm{SU}$ の $41.2 \pm 3.8 \mathrm{mg} / \mathrm{d} l$ と食事療法の $44.3 \pm 4.8 \mathrm{mg} / \mathrm{d} l$ には有意差はない. 故に SU 投与群の HDL-C は 食事療法群より低くはない。 
Sulfonylurea 剂治療中糖尿病患者の血中脂質に及ぼす Clinofibrate の影響

Diet $\quad(n=7)$

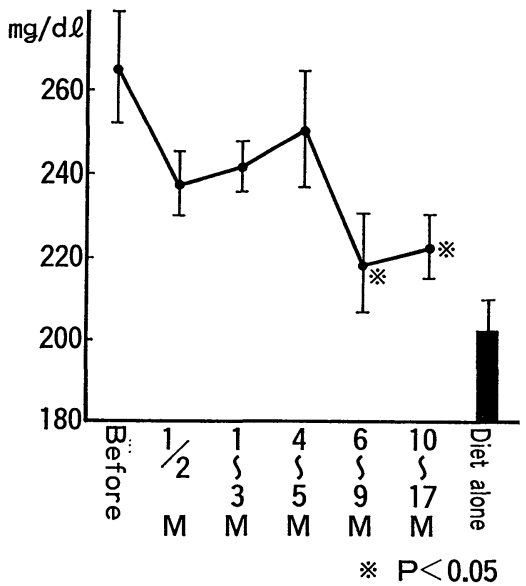

Sulfonyulurea $(n=17)$

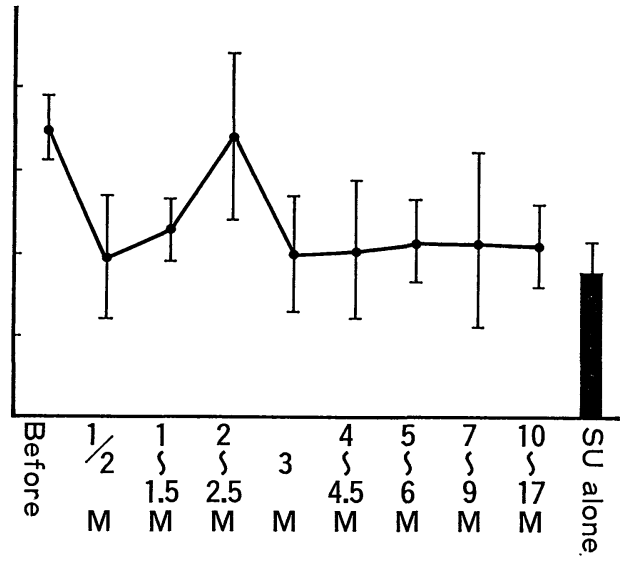

Fig. 1 Changes of blood cholesterol after Clinofibrate administration. $(M \pm S E)$

Diet $(n=7)$

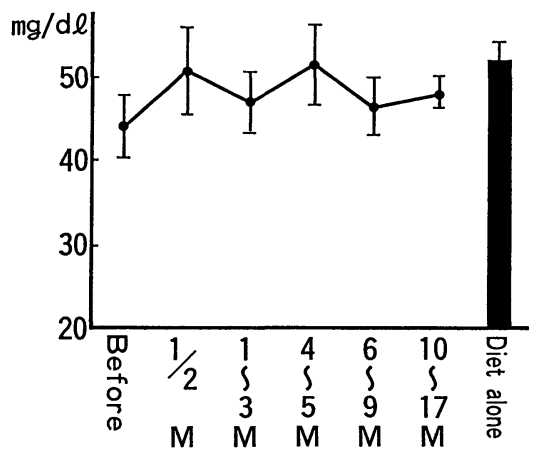

Sulfonylurea $(n=17)$

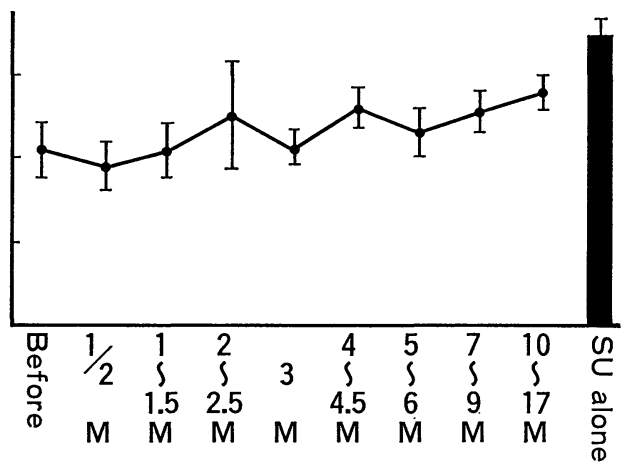

Fig. 2 Changes of blood HDL-Cholesterol after Clinofibrate administration. ( $M \pm S E)$

\section{Clinofibrate 投与後の脂質変動}

CF 投与後の脂質変動の経過を Figs. 1〜4 亿 示す. CH (Fig. 1) は投与 2 週ですでに低下する がその後食事療法群で 4 5 か月, SU 群で 2 2.5 か月にいわゆる rebound がみられた。しかし その後は再び低下状態をつづけ図の右端に示す正 常脂血症の平均值に向かい, CF の長期持続する 効果を示す.

HDL-C は Fig. 2 に示すように食事療法群では 軽度の動摇を繰返しながらも $\mathrm{CF}$ 非投与群の值に 近づく. SU 群では投与 2 か月で始めて前值の $41.2 \pm 3.8 \mathrm{mg} / \mathrm{d} l$ より $45.0 \pm 9.2 \mathrm{mg} / \mathrm{d} l$ と上昇傾向 を示し，以後漸増し 10１7 か月後では $47.7 \pm 2.9$ $\mathrm{mg} / \mathrm{d} l$ と平均値で $6.5 \mathrm{mg} / \mathrm{d} l$ 上昇，前值の $11.4 \%$ 増となった。

AI の変動 (Fig. 3) は HDL-C の変動より大き く CF 投与前值に対する増加 \% は食事療法群で $37 \%$ ，SU 群で $29 \%$ (Table 1) に達する．図から $\mathrm{AI}$ は CF 投与後食事療法群で 2 週後から, $\mathrm{SU}$ 群 でも 2 か月後から上昇し，10〜17 か月後には CF 非投与群の值に近づく.

TG の変動 (Fig. 4) は SU 群で著明で前値 263.2 $\pm 28.0 \mathrm{mg} / \mathrm{d} l$ より 2 週後には $165.8 \pm 18.9 \mathrm{mg} / \mathrm{d} l$ $(\mathrm{p}<0.05)$ と低下, 以後ほぼそのレベルを保って いる. しかし最終的にはなお $\mathrm{CF}$ 非投与群より高 值である．食事療法群でも2週後には前值の202.6 

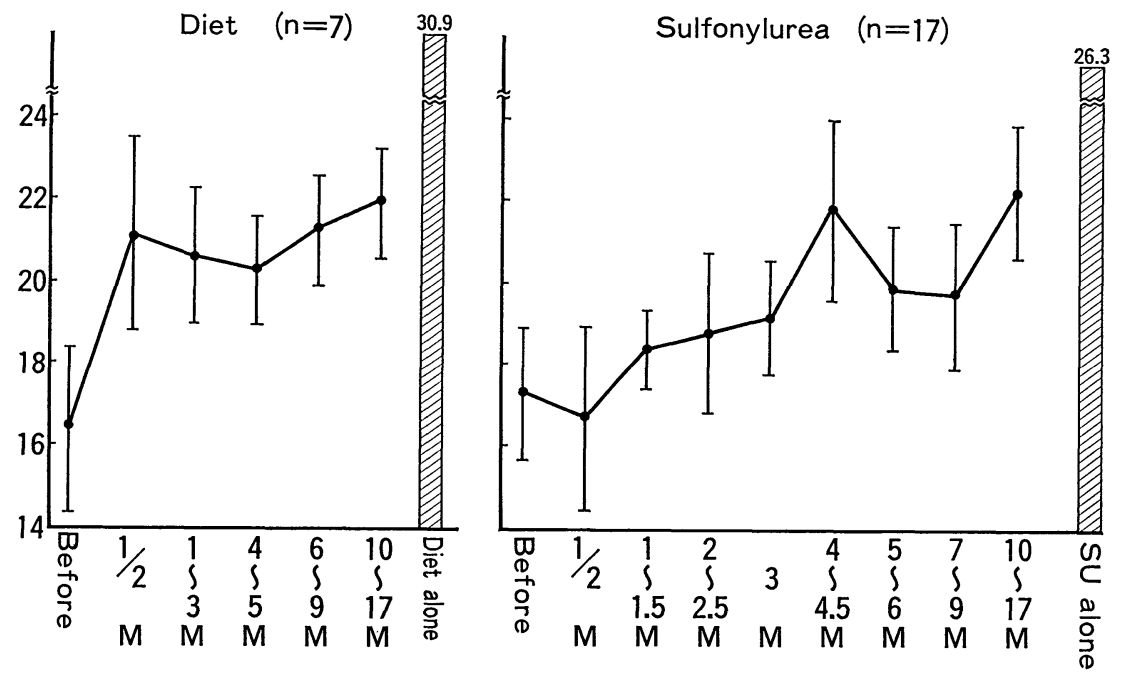

Fig. 3 Changes of atherogenic index after Clinofibrate administration.
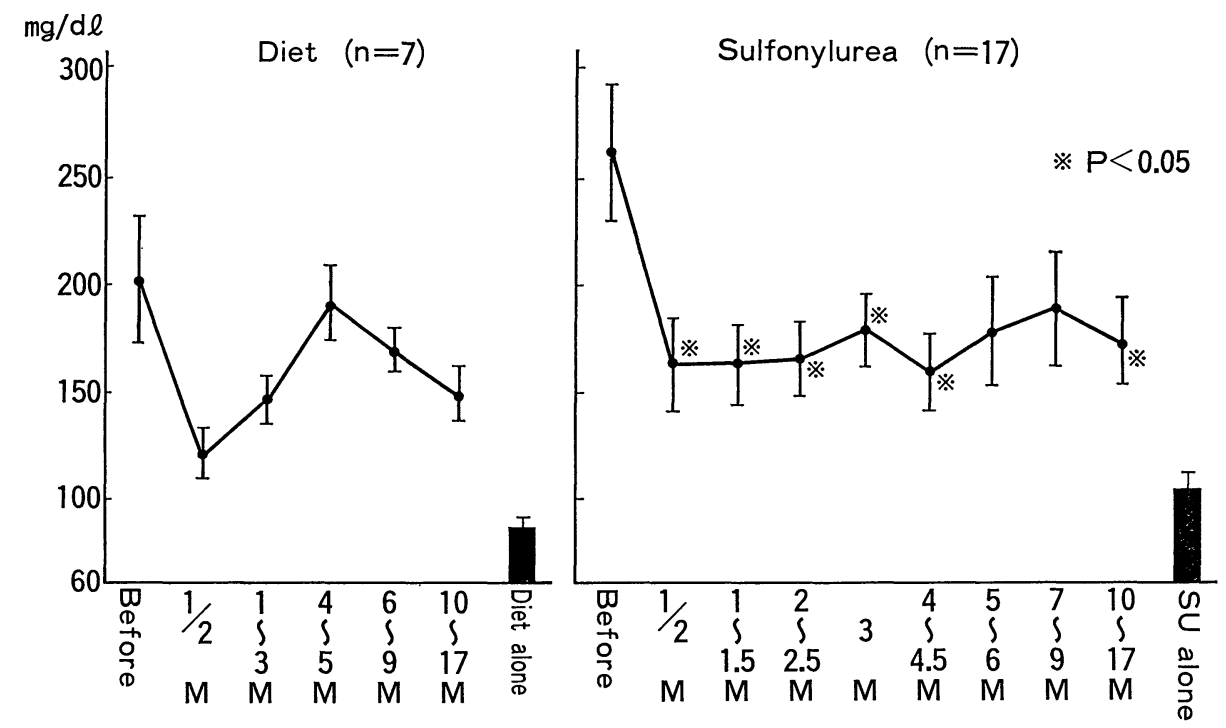

Fig. 4 Changes of blood triglyceride after Clinofibrate administration.

$\pm 30.9 \mathrm{mg} / \mathrm{d} l$ より $121.2 \pm 4.6 \mathrm{mg} / \mathrm{d} l$ に低下し, 以 後 rebound があるもののやはり非投与群の值に 近づいた.

\section{IV. 考案}

虚血性心疾患の発生率と HDL-C 濃度 は逆相 関するとの Framingham study の成績4) 以来, HDL-C は動脈硬化の risk factor として重要視さ れ，同時にその血中濃度に影響する諸因子に関す
る報告もすでに出つくしたとの感がある.すなわ ち HDL-C の上昇因子には運動, 軽度のアルコー ル，エストロゲェンなど，低下因子として肥満， 高脂血症, 脳硬塞, 糖尿病, 胆石症, さらにタバ コ、コーヒーもその可能性がある. SU むまた HDL-C を低下せしめると一部では報告された. しかし以上の因子が必ずしも常に HDL-C を上昇 または低下せしめるものではないようである.

そこで本研究では糖尿病臨床でもっとも繁用さ 
れる SU が HDL-Cを低下せしめるか否かをへ パリン・カルシウム法の改良法を使用して検討し たが, 少なくとも本研究に関する限り食事療法 群の HDL-C より低くはないとの結論を得た.

HDL-C の日本糖尿病学会総会における報告は昭 和 54 年〜 56 年がピークでこの 3 年間に 18 題あ るが, 成書の記載も含め SU との関係を整理する と (1) SU 内服の女性のみ HDL-C がインスリン, 食事療法群より低( ${ }^{5)}$, (2) 食事療法群に比べ低下 しない1)，(3) インスリン, 食事療法群と同 ゙゙2,6), (4) インスリン群より低いが食事療法群と同じ3), がある.したがってこれからも SU が食事療法よ り HDL-C を低下せしめるとは結論できない.わ れわれの研究対象は年齡と罹病期間をマッチし, 性差の検討はないが今回の成績はこの結論を支持 する. また一般に糖尿病では健常者に比し HDLCが低下との報告が多いが，われわれの未治療糖 尿病者の HDL-C は正常者より低下せず, 同様の 学会報告?)もみられる. HDL-C に影響する因子 は糖尿病という病態一つに限っても多数あり, し かも相反する見解がある. 例えば肥満, 年齢, 性差, 糖尿病コントロールが HDL-C 濃度に影 響1)するとする成績と逆に否定的な成績8) もある. したがってすでに報告されている諸因子が影響す る方向は必ずしも絶対的なものではないと思われ る.

SU が HDL-C を下降あるいは変動を与えない のいずれにせよ，SU 投与例の HDL-C を抗脂血 症剂が上昇せしめれば動脈硬化の risk を軽減せ しめる意味において糖尿病治療の目的にも叶い好 都合である. 糖尿病に伴った高脂血症の型別はわ れわれの成績9)によれば type IIb と IV が多く, したがって clofibrate, sinfibrate, nicomol な゙が 使われ，実際に sinfibrate では CH, TG の低下と HDL-C の上昇, nicomol では CH 低下 ${ }^{10)}$ が報 告されるが, clinofibrate, 特に 1 年を越す長期投 与の成績は未だ見当たらない.

今回の成績で CF は SU 群, 食事療法群の高脂 血症に対し投与 2 週間で $\mathrm{CH}, \mathrm{TG}$ を低下せしめ, rebound はあるもののその後は安定した長期の低 下作用を示すことが明らかとなった。一方HDLC に対しては効果発現は投与後 2 か月とおそい
が，以後は SU 群で約 1 年の観察終了時まで上昇 傾向をとった. CF は以上のような長期持続する 脂質代謝改善効果をもつが，さらに長期にわたる 今後の追跡研究が必要と思われる.

\section{V. ま め}

Sulfonylurea 剂で治療中の血糖調節の安定した 糖尿病患者 50 例のうちなお高脂血症を呈する 17 例に Clinofibrate $600 \mathrm{mg} /$ 日を約 1 年間投与し, 血中 Cholesterol, HDL-Cholesterol, Triglyceride の変動を測定した。一方食事療法群 22 例でも同 じく高脂血症を呈する 7 例に Clinofibrate を投与 し, 以下の結論を得た.

1) Sulfonylurea 投与群の HDL-Cholesterol は 未治療糖尿病または食事療法群に比べ低下はない。 また未治療糖尿病の HDL-cholesterol は正常対照 群より低下はない.

2) Clinofibrate は Sulfonylurea 投与群の Cholesterol, Triglycerideを 2 週後より低下せしめる が, HDL-Cholesterol は 2 か月後より上昇傾向 に向かわす. かつ上昇率は食事療法群より高い.

3) この脂質代謝改善効果は長期間持続 し, 1 年後においても減退しない.

\section{文献}

1) 家弓武矢. 河野泰子, 浜崎泰昶, 山下俊作, 小野直 子, 牧 俊子, 前田芳夫, 川 明: 糖尿病に抢ける HDL-cholesterol の変動について. 糖尿病, 24:490 (1981).

2）清水能人, 木畑正義, 田辺茂: 糖尿病に打ける HDL-コレステロールの検討. 糖尿病, 23: 494 (1980).

3) 白石正晴, 浜崎尚文, 徳盛 豊, 池田 匡, 富長将 人, 武田 倬, 安東良博, 真柴裕人：インスリン治 療糖尿病者の高 HDL-コレステロール血症の検討. 糖尿病, 23: 409 (1980).

4) Gordon, T., Castelli, W. P., Hjorland, M. C., Kannel, W. B. and Dawber, T. R.: High density lipoprotein as a protective factor against coronary heart disease. The Framingham Study. Am. J. Med., 62: 707-714 (1977).

5) 白石正晴, 西谷昭夫, 浜崎尚文, 徳盛 豊, 池田 匡, 武田 倬, 富長将人, 安東良博, 真柴裕人: 糖 尿病者における血清 HDL-コレステロールの検討. 糖尿病, 22: 355 (1979).

6) 板倉弘重: 糖尿病と血液脂質, 糖尿病, 合併症治療 のポイント. 池田義雄編, 日本メディカルセンター 東京, p. 95-104 (1983). 
動脈硬化 Vol. 12 No. 2 June 1984

7) 中村治雄, 石川俊文, 鈴木直記, 永野 充：糖負荷 時の HDL-コレステロール值. 糖尿病, 23: 491 (1980).

8) 辻 昌宏, 相川忠弘, 村尾 誠, 井出 肇, 加地 浩：糖尿病患者の HDL-cholesterol に対寸る肥満, 加齢, 性差についての検討. 糖尿病, 23: 493(1980).

9) Okuno, G., Tako, H., Kawakami, F., Fukuda, H., Kashihara, T., Takenaka, H. and Shibamoto, A.: Prevalence and course of vascular complications in diabetic patients with hyperlipemia in the Osaka district of Japan. edited by Melish, J. S., Hanna, $\mathbf{J}$. and Baba, S. in Genetic environmental interaction in diabetes mellitus. Excerpta Medica ICS 549 Amsterdam, p. 243-247 (1982).

10) 水野 治, 堀 昌子, 武井 泉, 谷山松雄, 鈴木 彰, 石沢 晋, 丸山 博, 片岡邦三, 松木 駿：糖 尿病患者における各種脂質代謝改善剂の効果検討. 糖尿病, 24: 255 (1981). 


\title{
Summary
}

\section{Effect of Clinofibrate on Blood Lipid of Sulfonylurea-treated Diabetics}

\author{
Giichi OKuno, Fusao Kawakami, Hajime Tako, Takeshi Kashinara, \\ Sigeki ShIBAmoto and Tatsue YAMAZAKI
}

Department of Medicine, Itami City Hospital

Sulfonylurea has been reported sometimes to reduce plasma HDL-cholesterol concentrations. In this study, 17 sulfonylurea-treated diabetics with sustained hyperlipemia under the steadystate blood glucose control received clinofibrate, an antilipemic agent, with a dose of $600 \mathrm{mg} /$ day for approximately one year or more. As controls of hyperlipemics, 33 normolipemic diabetics taking sulfonylurea were studied. Blood cholesterol, HDL-cholesterol and triglyceride were measured before and after 2, 4 weeks and thereafter each 2 months administration of clinofibrate. Seven hyperlipemic diabetics with dietary treatment were also investigated in the same manner as in the sulfonylurea-treated diabetics. The following results were obtained.

1. Plasma HDL-cholesterol concentrations under the continuous treatment of sulfonylurea are not lower than the concentrations of untreated diabetics or dietary-treated patients.

2. Serum cholesterol and triglyceride decreased 2 weeks after the administration of clinofibrate in sulfonylurea-treated diabetics and maintained the same or more lowered level throughout the observation period. Clinofibrate tends to increase plasma HDL-cholesterol concentration approximately 2 months after administration, followed by a gradual increase until the end of experiment in sulfonylurea group. The final HDL-cholesterol concentration was shown to be $117 \%$ of the initial level, slightly higher than the rate of increase in dietary-treated group.

3. The effect of clinofibrate on improving lipid metabolism in sulfonylurea-treated diabetics appears to last for a long period, and does not disappear at least after one year's administration.

Key words: Sulfonylurea, Clinofibrate, Diabetics, Hyperlipemia, HDL-Cholesterol. 